Relations industrielles

Industrial Relations

\title{
Collective Agreement Act
}

\section{Marcel Forget}

Volume 2, numéro 9, mai 1947

URI : https://id.erudit.org/iderudit/1023880ar

DOI : https://doi.org/10.7202/1023880ar

Aller au sommaire du numéro

Éditeur(s)

Département des relations industrielles de l’Université Laval

ISSN

0034-379X (imprimé)

1703-8138 (numérique)

Découvrir la revue

Citer cet article

Forget, M. (1947). Collective Agreement Act. Relations industrielles / Industrial Relations, 2(9), 3-8. https://doi.org/10.7202/1023880ar

Tous droits réservés @ C Département des relations industrielles de l’Université Laval, 1947
Ce document est protégé par la loi sur le droit d'auteur. L’utilisation des services d'Érudit (y compris la reproduction) est assujettie à sa politique d'utilisation que vous pouvez consulter en ligne.

https://apropos.erudit.org/fr/usagers/politique-dutilisation/ 


\section{LOI DE LA CONVENTION COLLECTIVE}

VI.-Dispositions de la convention collective qui sont l'objet du decret:

1.-Dispositions essentielles:

Les dispositions de la convention collective, qu'elles aient été modifiées ou non par le lieutenant-gouverneur en conseil, qui deviennent obligatoires par le fait $\mathrm{d}$ ə l'extension juridique et qui partant lient aussi bien les parties non-contractantes que les parties contractantes, sont les dispositions ncrmatives qui se rapportent:

a) au salaire,

b) à la durée du travail,

c) aux congés payés,

d) à l'apprentissage et

e) au rapport entre le nombre des ouvriers qualifiés et celui des apprentis dans une entreprise donnée (art. 9).

2.-Dispositions accessoires:

Le lieutenant-gouverneur en conseil peut aussi rendre obligatoires, avec ou sans modification, les dispositions de la convention collective qui ont trait:

a) aux allocations familiales,

b) à la classification des opérations,

c) à la détermination des différentes catégories de salariés et d'employeurs,

d) ainsi que celles qu'il estime conformes à l'esprit de la présente loi (art. 10).

N. B.-A remarquer qu'il n'est pas question de fixer dans le décret les prix à être chargés au public pour les services rendus ou les produits vendus, sauf pour les barbiers-coiffeurs (art. 10).

\section{VII.-Effets du décret:}

Les dispositions du décret sont d'ordre public, c'est-à-dire qu'elles ont préséance sur eelles de toute convention individuelle, de toute convention collective signée en vertu de la Loi des relations ouvrières ou de la Loi des syndicats professionnels, et de toute ordonnance de la Commission du salaire minimum. Elles régissent, dans la juridiction déterminée, tout louage de travail de même nature que celui visé par la convention collective (art. 11).

Il est défendu de stipuler dans un contrat de travail individuel ou une convention collective de travail particulière un salaire différent de celui fixé par le décret (art. 12). Toutefois, les dispositions d'un louage de travail, lorsqu'elles sont à l'avantage du salarié, produisent leur effet, à moins qu'elles ne soient expressément interdites dans le décret (art. 13).

(1) Le premier article de cette série a paru dans le numéro de mars.
L'employeur professionnel qui a habituellement à son emploi des salariés pour un genre de travail affecté par le décret et qui contracte avec un sous-entrepreneur ou sous-traitant, directement ou par intermédiaire, est solidairement responsable avec ce sousentrepreneur ou sous-traitant et tout intermédiaire du paiement du salaire fixé par le décret (art. 14).

N. B. $-A$ noter que l'employeur qui n'a habituellement à son emploi qu'un seul salarié n'est pas regardé comme employeur professionnel au sens de la présente loi.

\section{VIII.-Effets de la publication du décret}

La publication du décret dans la Gazette officielle de Québec rend non recevable toute contestation au sujet de l'incapacité des parties à la convention, de la validité de cette dernière et de l'insuffisance des avis. Et à tous autres égards, elle crée généralement une présomption «juris et de jure» qui établit la légalité de tous les procédés relatifs à son adoption (art. 15).

N. B.-En droit il existe delıx espèces de présomption: la présomption «juris tantum 》 et la présomption «juris et de jure 》,

La présomption «juris tantum » prévaut en l'absence de toute preuve contraire; elle peut donc être refutée. Par contre, la présomption «juris et de jure » ou la présomption invincible ne saurait être repoussée par aucune preuve contraire; elle est décisive.

\section{IX.-Durée du décret:}

Le décret entre en vigueur

a) à compter du jour de sa publication dans la Gazette officielle de Québec ou

b) de la date ultérieure qui y est fixée (art. 7), et

c) a même durée que la convention collective de travail qu'il rend obligatoire. (Voir Loi des relations ouvrières, art. 15).

Par arrêté ministériel dont avis doit toujours être donné dans la Gazette officielle de Québec, le décret peut:

a) ètre prolongé

b) être en tout temps abrogé, et

c) être en tout temps modifié après consultation avec les parties contractantes ou sur requête expresse desdites parties.

La prolongation du décret prend effet à compter du jour de sa ratification.

L'abrogation du décret prend effet à compter du jour de sa publication dans la Gazette officielle de Québec.

La modification du décret prend effet à compter du iour de sa publication dans la Gazette officielle de Québec ou de la date ultérieure qui y est fixée (art. 8).

Marcel FORGET

\section{COLLECTIVE AGREEMENT ACT}

\section{VI.-Provisions of a collective agreement}

which are the object of the Decree:

1.-Essentiel provisions:

The provisions of a collective agreement, whether they are madified or not by the Lieutenant-Governor-in-Council, which become obligatory by the fact of juridical extension and which also bind non-contracting parties as well as contracting parties, are the basic provisions respecting:

a) wages,

b) hours of labor,

c) paid holidays,

d) apprenticeship, and

e) the proportion between the number of skilled workmen and that of apprentices in a given undertaking.

2.-Accessory provisions:

The Lieutenant Governor in Council may also render obligatory with or without modification the provisions of a collective agreement respecting:

a) family allowances,

b) the classification of operations,

c) the determination of the various classes of employees and employers,

(1) The first article of this series has been published in the March issue. d) and such other provisions as the Lieutenant Governor in Council may deem in conformity with the spirit of this Act (Art. 10)

N. B.-It is to be noted that there is no question of fixing in the Decree the prices which are to be charged to the public for services rendered or products sold, except in the case of barbers and hairdressers. (Art. 10).

\section{VII.-Effects of the Decree}

The provisions of the Decree entail a matter of public order, that is to say they have precedence over the provisions of any private agreement, any collective agreement passed in virtue of the Labour Relations Act, any collective agreement passed in virtue of the Professionnal Syndicates Act, and of any ordonnance of the Minimum Wage Commission.

The provisions of a Decree govern within a determined jurisdiction every type of work of the same nature or kind as that contemplated by the collective agreement (Art. 11).

It is forbidden to stipulate in any private contract or in any private collective agreement a wage different from that fixed by the Decree (Art. 12). However, the provisions of a lease and hire of work, when they are more advantageous to the employee, are valid, unless they are expressly forbidden by the Decree (Art. 13).

The professional employer who habitually has in his service employees doing work affected by the Decree and who contracts with a sub-entrepreneur or sub-contractor, directly or through an intermediary, is jointly and severally responsible with such

$$
\text { (Continued on page 8) }
$$




\section{Les fonctions du directeur de personnel}

Le premier principe qui doit guider l'action d'un directeur de personnel, c'est celui de la justice. On ne doit pas oublier qu'il y a 1ci deux parties en caltse: l'employe et l'entreprise. Le directeur de personnel a une double personnalité: lorsqu'il traite avec la direction de l'établissement, il doit prendre la part du salarié et lorsqu'il traite avec les employés, il doit représenter les intérêts de l'entreprise. Malgré que cette situation puisse sembler singulière il doit en être ainsi afin que le directeur de personnel remplisse efficacement sa fonction.

Le directeur de personnel doit penser en termes de coût de production. Dans l'accomplissement de sa tâche il ne doit pas perdre de vue les fonctions principales de l'entreprise qui se résument à l'emploi de main-d'oeuvre et la réalisation d'un profit. Il doit porter son attention sur le coût de production tout comme le contremaitre à l'usine; il doit même s'en préoccuper davantage puisque sa fonction le place à un poste supérieur.

Parce que ses fonctions en font un homme responsable, le directeur de personnel, à mon avis, doit relever du président du conseil d'administration. Il n'est pas un officier ordinaire qui reçoit ses directives d'un autre; ses attributions, difficiles de délimitation, l'obligent à beaucoup d'initiative. Aussi importe-t-il que l'entreprise accorde une attention de plus en plus marquée aux fonctions du service de personnel. Il est aussi nécessaire de s'occuper des relations humaines que des relations publiques.

La responsabilité de la propagande et de la publicité intérieures incombe au directeur de personnel. Dans une grande entreprise où l'on rencontre un contingent nombreux d'êtres humains, il est indispensable que quelqu'un s'occupe attentivement de la publicité, afin que les employés soient informés de ce qui s'y passe, en vue de pouvoir, le cas échéant, ne pas se laisser influencer par une propagande insidieuse.

\section{Les registres}

L'exécution du travail confié au directeur de personnel, exige la tenue de registres complets d'employés. Une entreprise ne peut être conduite sans l'aide d'états appropriés sur les prix de revient; de même est-il impossible de diriger un service de personnel sans un système adéquat de registres d'employés. Je ne saurais trop insister sur ce point, tellement il a été négligé en ces dernières années.

Il doit y avoir une politique bien définie à l'égard de tels registres et cette politique doit s'inspirer du système conventionnel de comptabilité. On doit poser en principe qu'à compter du jour où un employé est embauché jusqu'au moment de son départ, un système approprié de registres doit contenir fidèlement tout ce qui s'y rapporte. On doit aussi conserver dans un livre journal l'inscription des noms des employés embauchès, congédiés et transiérés.

Une fiche doit être faite au nom de tout nouvel employé et classée au bureau. On doit aussi pourvoir à des formules d'embauchage, de congédiement, de changement de taux, de transfert, etc., d'employés et l'histoire complète de chacun doit apparaître sur une fiche à cette fin. Au départ définitif d'un employé, ses fiches doivent être transférées aux archives et classées selon l'ordre alphabétique. De cette façon, s'il devait revenir plus tard, le

\section{LE DIRECTEUR}

service de placement aurait l'histoire complète de son stage à l'usme et advenant son retour au travail, ses fiches n'auraient qu'à être versees aux dossiers courants.

Les formules destinées au service de placement doivent viser surtout à l'efficacité. C'est pourquoi elles doivent être conçues de façon qu'elles puissent servir à de multiples usages tout en étant peu nombreuses. La tenue soignée d'un fichier au service de placement relève du directeur de personnel.

\section{L'embauchage et le congédiement des employés}

La responsabilité de l'embauchage et du congédiement des employés doit reposer totalement sur le directeur de personnel. Quand les contremaitres requièrent de nouveaux employés, ils doivent faire parvenir une requisition au service de personnel de la même façon qu'une demande de matériel est adressée au service d'achats. Ce qui ne veut pas signifier qu'un directeur de personnei puisse obliger un contremaître à accepter n'importe qui. Car c'est la fonction du directeur de personnel de découvrir les sujets de choix que l'usine aura intérêt à accueillir, comme c'est celle du service d'achats de procurer à l'usine de bons approvisionnements. Il est important de souligner, toutefois, que l'embauchage au hasard par le contremaitre ne devrait pas être permis. J'ai fréquemment observé que des contremaitres accordaient leur préférence aux parents et amis, etc., alors qu'en règle générale on doit embaucher que des hommes pouvant servir efficacement.

Dans l'éventualité d'un congédiement, le surintendant ou le contremaitre concerné avisera le directeur de personnel que les services d'un employé désigné ne sont plus requis. Il appartient alors au directeur de personnel de contrôler si aucune injustice n'est faite à cet employé en le congédiant. Il y a des lois en notre pays qui prescrivent ce qui doit être fait en de telles circonstances, et le directeur du personnel doit en tenir compte.

Toute augmentation de salaire doit être présentée sous la forme d'une recommandation au directeur de personnel, qui à son tour, s'il y accède, la fera confirmer par le président du conseil d'administration. A mon avis, toute recommandation en vue d'une augmentation du salaire d'un employé individuel devrait être examinée à fond afin de déterminer en premier lieu si cette augmentation est justifiée et ensuite, si elle, correspond à la politique de la compagnie, ou si elle contrevient au taux payé à des employés exécutant un travail identique. Je crois fermement qu'en cette matière, les contremaitres ne devraient pas avoir le dernier mot.

Le directeur de personnel, lors d'une demande de nouveaux employés, doit s'efforcer' de compléter les cadres à même ceux qui sont déjà au service de l'établissement, plutôt que d'engager sans discernement. Il agit alors comme le pourvoyeur qui cherche à satisfaire aux demandes de matériel d'après ce qu'il a en stock plutôt 


\section{PERSONNEL}

que d'acheter d'autres marchandises. En plusieurs occasions, le directeur de personnel, s'il en fait l'essai, réussira à transterer un employé à un autre département et combler ansi la vacance sans ajouter à la iiste de paie.

\section{Relations avec les syndicats}

Les relations avec les unions ouvrières doivent être faites par l intermediaire du directeur de personnel. Let ofticier do.t connaitre parfaitement les lois et règlements relàtifs au travall. Son role l'oblige aussi à determiner ce qui ne doit pas faire l'objet des conventions collectives cie travari. Lans tous les cas, l'officier de placement doit s'occuper des relations avec les chefs ouvriers qu'il doit s appliquer à connaitre personnellement afin de les convancre de ses intentions droites ainsi que de son désir de traiter avec eux et de s'en tenir aux conventions signées.

Le directeur de personnel ievrait régler tous les griefs; plus il en élıminera, moins nombreuses seront les difficultés avec les ouvriers. Constamment attentif, il devra s'efforcer d'ajuster et d'éliminer les griefs avant qu'ils rie. s'aggravent.

\section{Services médicaux}

L'engagement du personnel soulève une multitude de problèmes dont l'établissement d'un service médical à l'usine. Si le surintendant de personnel veut remplir efficacement sa fonction, il doit s'en occuper lorsqu'un tel service fonctionne déjà. . Il est important afin que la compagnie n'emploie pas de personnel souffrant de maladies. contagieuses ou de déficiences pouvant conduire à des accidents industriels. Le directeur de personnel doit se plier à ces exigences. S'il y a un plan de pension de retraite, il doit apporter une attention particulière à l'âge et à l'état physique de l'employé.

\section{Services de prévention}

I1 faut aussi considérer l'établissement de services sécuritaires. A mon avis, l'officier de sécurité à l'usine doit relever du directeur de personnel à qui il appartient d'élaborer les règlements du service de sécurité et de voir à ce que les assemblées de ce service soient tenues régulièrement. Il doit aussi y assister et prendre connaissance des procès-verbaux des réunions. Il lui revient, en outre, d'établir les règlements sécuritaires et, ce qui est important, de s'en faire le propagandiste. Il doit mettre tout le soin nécessaire à la diffusion des idées de sécurité à l'usine et s'occuper de la tenue des rapports relatifs à l'expérience accidentelle.

\section{Régime d'apprentissage}

Afin que l'entreprise ait à sa disposition une réserve constante de main-d'oeuvre qualifiée, le directeur de per- sonnel doit être responsable de l'exécution d'un programme dentrainement. Il doit rédiger à cette fin, un cours de formation professionnelle prévoyant un entrainement methodique et s'assurer qu'un nombre suffisant d'apprentis passent par tous les stages prévus. C'est également une pratique qui s'est avéree très avantageuse que celle d'embaucher des étudiants durant leurs vacances d'été. Le directeur de personnel doit se tenir en étroite relation avec les écoles de métiers et les universités en vue de rechercher les étudiants désireux d'offrir leurs services à i'entreprise au cours de leurs vacances et de lui procurer ainsi un personnel de choix.

\section{Bien-être et cantines}

Les activités reiatives au bicn-être des employés, teiles celles se rapportant aux associations de secours mutuel, aux bénéfices en maladie, au plan d'assurance-vie, etc., et aux cantines ne doivent pas laisser indifférent le dir ecteur de personnel. Bien plus, il doit coordonner ces activités et favoriser l'étude, dans les cercles d'employés, des problèmes relatifs à leur bien-être. C'est un grand avantage pour une entreprise que d'être assurée que quelqu'un s'occupe du bien-être de son personnel. Dans une communauté humaine il y a toujours quelqu'un qui requiert de l'aide dans ses difficultés, le directeur de personnel doit pouvoir assurer ce service. Il sera facilité par l'élaboration d'une organisation commune pour tous les travailleurs selon la formule coopérative. Les cantines, en raison de leur grande utilité pour le personnel, exigent une surveillance étroite, et les profits réalisés, si possible, doivent être versés à un fonds de secours.

J'ai déjà souligné la nécessité de connaitre les coûts de production. En autant qu'il sera possible, le directeur de personnel devrait avoir eu l'avantage de passer par tous les rouages de l'entreprise et posséder une connaissance précise des diverses fonctions productives. Quoiqu'il en soit, il est indispensable qu'il étudie les diverses occupations. Il importe qu'il connaisse la technique de l'évaluation des tâches afin de lui permettre de parler de celles-ci intelligemment. La question de l'«étude des temps » est aussi essentielle. Je crois que dans plusieurs maisons d'éducation on a complètement négligé d'y attacher de l'importance. Pourtant, elle est maintenant une question de premier plan dans l'industrie et un directeur de personnel ne doit pas l'ignorer. Il peut en être question dans' la politique d'établissement des taux de salaire et dans les relations avec les unions ouvrières.

Enfin, j'attire votre attention sur la nécessité de contacts quotidiens à l'usine. La place du directeur de personnel n'est pas en face d'un bureau. Il doit être constamment à l'usine, en relations avec les occupations et le personnel; il doit entretenir de fréquentes conversations avec les contremaitres sur leurs besoins. De cette façon, les griefs lui seront formulés et il pourra prendre action. A mon avis, plusieurs de ces griefs sont justifiés; d'autres s'appuient sur des informations fausses qu'il peut alors rectifier. Le directeur de personnel doit, de toute nécessité, prendre le temps de considérer et de régler les griefs. Si une entreprise vient à laisser au chef ouvrier le soin de lui faire des recommandations en vue de l'inciter à mettre ordre à cet état de choses, alors qu'elle peut autrement y remédier, c'est avouer que le directeur de personnel a failli à sa tâche.

T. Roger McLagan 


\section{THE PERSONAL MANAGER}

\section{FUNCTIONS OF A PERSONNEL MANAGER}

In my opinion, the cardinal principle which should be followed by a Personnel Manager is one of justice. In speaking of justice, it should be rememocred that there are two parties involved, namely, the Employee and the Management. He is a dual personality. When he i.s negotiating with the Nianagement, he should be taking the part of the Employee, and when he is negotiating with the Employees, he should be taking the part of the Management. It may seem to be a pecullar function, but that is what must be kept in mind if a Personnel Manager is to be successful.

The next point to be kept in mind is that a Personnel Manager must be cost minded. Just because he is in charge of personnel does not mean that he has a closed mind to the main functions of the business, which are to employ people and make a profit. He should be just as cost minded as the Superintendents in the Plant. In fact, he should be more so as he is really in a higher Executive post.

The Personnel Manager, in my opinion, is a very important person, and he should be responsible to the Chief Operating Executive. $\mathrm{He}$ is not just an ordinary person who is taking orders from someone else, but he should be a man of great initiative, because he is performing functions for which it is difficult to evolve a set of detailed rules. In my opinion, more and more attention has got to be paid by Business to the functions of the Personnel Department. It is just as important to pay attention to the human relations as it is to the Public Relations.

The Personnel Manager should be considered in charge of internal publicity and propaganda. In a large organization where there are a lot of human beings, it is necessary for someone to carefully arrange the publicity so that the employees are posted on what is going on and so that bad propaganda can be counteracted.

\section{OFFICE RECORDS}

As regards the operating functions of a Personnel Manager, it is important that very accurate office records be kept of employees. You cannot operate the business without cost records and, therefore, you cannot operate an Employment Department without a proper set of office records. I cannot stress this matter too much, as it is one which has been sadly neglected over the years.

There should be a well defined Standard Practice regarding the records to be kept. It should follow conventional bookkeeping records. The guiding principle should be that from the time that a man is hired to the time that the man is discharged or leaves the employ of the Company, a complete set of records should be kept as to what has happened to him. There should be an office journal showing those who are hired and discharged and transferred.

Upon entry into the Plant, a history sheet should be made out, and it should be filed in a folder in the Office. There should be forms made out for the hiring, firing, change of rate, transfer, etc., of the man, and all this history should appear on a convenient form in the Office. If the man should leave, his records should be gathered up and placed in a dead file in alphabetical order. In this way, if this man should return, the Employment Utticer has the full record of his history in the Plant and, if he is a suitable employee for reemployment, his record is simply taken out of the dead file and put in the live file.

'I hese Employment Office forms should not be voluminous, but they should be very efficient and they should be carefully made out so that one form may do for a number of different functions. The Personnel Manager should see that the Employment Office records are meticulously kept.

\section{HIRING AND DISCHARGING OF EMPLOYEES}

The Personnel Manager should be in complete charge of the hiring and discharging of all employees. When Superintendents require new men, they send a requisition for same to the Personnel Department in the same way as they send a requisition for materials to the Purchasing Department. This does not mean that the Personnel Manager can force Superintendents to take any kind of a man. It is the function of a Personnel Manager to seek out good men and get them into the Plant in the same way as the Purchasing Department seeks out good materials to be used in the Plant. The main point, however, is that the indiscriminate hiring of employees by Foremen should not be allowed. I have found, in many cases, that Foreman will tend to get their Department filled with relatives or friends, etc., and we are hiring men for their use as efficient operators.

Where men have to be discharged, the Superintendent of Foreman concerned will notify the Personnel Manager that he no longer needs such an employee. It is up to the Personnel Manager, in the first place, to see that no injustice is being done in discharging this particular person. We have laws in this country which prescribe what we are to do, and the Personnel Manager is required to see that those laws are followed.

All raise increases should be in the form of recommendations for a raise to the Personnel Department, who, in turn, no doubt, will have it confirmed, if he concurs, by the Chiet Executive Officer. In my opinion, recommendations for increasing individuals' wages should be very carefully scrutinized to see that, first, such an increase is justified, and secondly, that it is not out of line with the policy of the Company or in relation to other employees performing the same function. I feel strongly that Foremen do not have the final say in what the employees' wages are going to be.

On this policy of hiring and firing employees, the Personnel Manager, when asked for new employees, should try and fill the requisition from existing staff, rather than hire indiscriminately. This founction is performed by a Storekeeper, who will try and fill his material requisitions from stock rather than buy new goods. In many cases, a Personnel Manager, if he tries, can sometimes transfer an employee from one Department to another-and fill the vacancy without increasing the payroll.

\section{RELATIONS WITH TRADE UNIONS}

All relations with Trade Unions should be through the Personnel Manager. He should be a man that has the knowledge of the existing Labour rules and regulations at his finger tips. He should see that a proper set of ruies 
of work are made up, which may or may not be part of a Trade Union Agreement. In any event, the Employment Supervisor should carry out all the relations with the Union Leaders, and he should make it his business to know them personally and to convince them of his honesty and desire to deal with them and live up to their agreements.

The Personnel Manager should settle all disputes, and the more disputes he settles the less troubles with labour there will be. $\mathrm{He}$ should be a regular listening post of the Company, and should try and eliminate disputes or aggravations before they become serious.

\section{MEDICAL SERVICES}

The hiring of new employees brings us to the question of a medical service in the Plant, and an efficient Personnel Supervisor should be the Officer of the Company in charge of the Medical Services, if there be one. It is important that employees be medically examined before being taken on, so that the Company does not employ men with contagious diseases or men with disabili$t$ es which are liable to involve them or their fellows in an accident in the Plant. It is important that the Personnel Manager observe these matters very strictly and, if there be a Pension Service in the Company, he should pay particular attention to the age and physical ability of the employee.

\section{SAFETY SERVICES}

This brings us also to the Safety Service. In my epinion, the Safety Supervisor of the Plant shotld report to the Personnel Manager. The Personnel Manager should draw up very carefully the rules and regulations of the Safety Service, and he should see that meetings of the Safety Committee are properly carried out, attending all the meetings and carefully reading all the minutes of the meetings. He should draw up a careful set of safety regulations and, here again, internal propaganda is very important. He should be careful to see that the cause of safety is promoted in the Plant and, again, the matter of safety records efficiently kept shouid be carried out.

\section{APPRENTICE SYSTEM}

In order that a supply of well trained young meis are constantly passing through the organization, the Personnal Manager should have charge of the Apprentice system. He should see that the correct number of apprentices are constantly moving up through the various trades. He should lay out for them the course of instruction they should have and, more important, he should see that these boys are moved from function to function so that they are getting properly trained. In this connection, also, I might mention the policy of summer students into the Plant in the summer month several years before they graduate so that he can obtain first class material for the Plant.

\section{WELFARE AND CANTEENS}

He should be in charge of all employees' welfare activities, such as Mutual Benefit Associations, Sick
Benefit, Life Insurance schemes, etc., and canteens. Where possible, all these activities should be co-ordinated, and he should encourage the study of the welfare of all the employees by Committees of the employees. It means a great deal to an organization to have someone watching over the welfare of its people. Where a large body of men is concerned, there is always someone getting into trouble or someone needing help, and the Personnel Manager should see that this help is forthcoming. It is best done by the organization of all the workers into a $\mathrm{CO}_{\text {- }}$ operative welfare scheme. The supervision of the canteens is most important because they are being used by the men and, where possible, the profits of these canteens should go to the Welfare Fund.

I have mentioned before the matter of knowledge of cost of production. Where possible, the Personnel Manager should be a man who has come up through the organization and has a knowledge of the various productive functions. Whether he has come up through the organization or not, it is most essential he should study the various jobs or trades in those Departments. $\mathrm{He}$ must have a knowledge of job evaluation, and he should be able to talk intelligently about the various jobs. In this connection, I mention the question of time study. I find in various educational institutions, that emphasis on this has been completely neglected. It is a most important matter in industry today, and it is one which a Personnel Manager should have some knowledge of. It may come up in the policy of wage rates and in the relations with Trade Unions.

I finally bring up the question to you of daily contacts in the Plant. The Personnel Manager should not be one who sits in an office chair. He should be constantly out in the Plant keeping in touch with the operations and talking to the various men, and conferring with the Foremen about their needs. By doing so, he will hear of the various little complaints of the men and, in my opinion, many of these complaints are either justified or based on misinformation. The Personnel Manager must, of necessity, take the time to run these down and keep down complaints. If an organization lets a Labour leader come down and make that organization correct some grievances which the organization should have done itself, then it means that the Personnel Manager has fallen down on the job.

\section{T. Roger McLagan}

\section{NOS COLLABORATEURS}

Dion. Gérard, L.Th., L.Ph.. M.Sc.Soc., secrétaire du Département des relations industrielles de l'Université Laval.

Forget, Marcel, secrétaire adjoint de la Fédération des comités paritaires de la province de Québec.

McLagan, T. Roger. Member Canadian Engineering Institute, de la firme Dufresne, McLagan and Associates, Reg'd., et gérant général de Canadian Vickers Limited, Montréal.

Quimper, Donat, LL.L., directeur adjoint du Service de conciliation et d'arbitrage du ministère du Travail. 


\section{DU RÉGLEMENT DES GRIEFS SOUS LE RÉGIME DE LA CONVENTION COLLECTIVE}

Si la paix industrielle dépend du bon fonctionnement des relations ouvrières-patronales, celles-ci à leur tour dépendent pour beaucoup de l'habileté des parties à prévenir les causes possibles de conflits et à régler rapidement ceux qui peuvent surprendre leur vigilence. Une procédure de règlement de griefs dans la convention collective est le moyen par excellence qui permette aux parties de régler elles-mêmes leurs difficultés commune et de protéger ainsi l'harmonie de leurs relations.

La procédure de griefs donne aux parties la confiance que leurs différends seront réglés directement par voie démocratique. Elle est une soupape de sûreté contre les explosions possibles de mécontentement.

Comme caractéristiques générales, une bonne procédure de griefs comporte une série d'étapes de négociations qui commencent entre le plaignant et le contremaître et se poursuivent par mode d'appels successifs jusqu'aux officiers supérieurs de TUnion et de la Compagnie. A ce stade, si aucun règlement n'est réalisé, un tribunal d'arbitrage ou un arbitre nommé «ad hoc» par les parties rend une décision finale.

Dans son fonctionnement, ce mécanisme ne doit pas être détourné de ses fins. Il doit servir à procurer la justice, à protéger le droit, à sauvegarder la paix. Si on en fait un mauvais usage, les justiciables lui retireront leur confiance, et seront bien exposés, dans l'éventualité d'un grief, à chercher plutôt à se faire justice à eux-mêmes.

La procédure de griefs doit procurer des règlements au mérite. Chaque cas doit être étudié dans son cadre particulier et jugé selon l'équité et la bonne conscience.

Les griefs doivent en outre être réglés autant que possible à leur point d'origine. En effet, la difficulté du règlement s'accroît si le grief dépasse les premiers stades parce que les parties sont portées à mesurer son importance au prestige ascendant des personnes qui entrent en scène aux différentes étapes.

Enfin, les griefs doivent être réglés promptement; sinon on expose la procédure à l'embouteillage par laccumulation des plaintes non réglées. A cette fin, il est extrêmement important de réduire au minimum le nombre d'étapes de la procédure. Evidemment celle-ci doit comporter suffisamment de phases pour que les parties aient toute l'opportunité possible d'en arriver à un accord par le jeu des négociations. Mais, il est clair aussi, que la multiplicité des stades est susceptible d'entraîner des retards. Il est une règle cependant qu'on peut énoncer d'une façon catégorique: à chaque nouveau stade, les représentants des parties doivent personnifier une autorité plus haute et exprimer un point de vue plus large que ceux qui ont agi antérieurement. Tout appel à un stade supérieur doit offrir des chances additionnelles de règlement.

Doit-on fixer des délais limite pour porter plainte, en appeler aux différents stades et rendre les décisions?

D'aucuns prétendent que sans de tels délais la procédure est plus souple, et qu'au surplus, les parties de mauvaise foi en usent au maximum pour retarder les règlements. Cette deuxième partie de l'objection nous procure une raison additionnelle en leur faveur; car si les parties de mauvaise foi en abusent à la limite, que serait-ce s'il n'y en avait pas du tout! I.es délais limite sont une sauvegarde contre l'obstruction et la négligeance. Ils soutiennent le moral de l'employé en l'assurant que dans une période donnée, il recevra une réponse à ses plaintes. De son côté, l'employeur peut compter qu'à l'expiration d'un délai déterminé, les plaintes retirées ou abandonnées ne réapparaîtront pas indéfiniment.

Enfin, les griefs devraient être traités par écrit dès le premier stade pour l'excellente raison que l'écrit décourage les plaintes superficielles. Le fait d'avoir à porter une plainte ou à rendre une décision sous sa signature fait prendre davantage conscience de sa responsabilité. L'écrit réduit l'argumentation sur les faits et empêche les parties de se dédire au cours de la procédure.

On discute souvent aussi les questions de savoir si l'Union doit entrer dans la procédure dès le premier stade et si les contremaîtres doivent participer au règlement des griefs. Nous croyons que l'Union, en thèse générale, devrait s'occuper des griefs dès le commencement parce que l'employé a droit au secours et à la protection morale de son Union et que celle-ci pourra présenter sa plainte plus objectivement. De cette façon, l'Union pourra dès le début éliminer un grand nombre de plaintes non fondées pour éviter l'encombrement de la procédure.

Le recours au contremaître est recommandé mais à la con- dition qu'il ait suffisamment d'autorité pour décider des plaintes qui lui sont présentées.

Jamais il ne devrait être question de modifier ou d'abroger certaines clauses du contrat au moyen de la procédure de griefs, autrement tout le contrat deviendrait sans valeur.

Enfin, la meilleure procédure de griefs ne vaudra rien, si les parties n'y apportent les dispositions essentielles de bonne foi, de confiance et de respect mutuel. Ge qui compte ce ne sont pas les dispositions du contrat, ce sont les dispositions des personnes. L'honnêteté d'intention et la conscience que les griefs sont des problèmes d'intérêt commun, vaut infiniment mieux que la procédure la plus parfaite.

Si la confiance n'existe pas ou si la mauvaise foi domine ies rapports, la procédure n'empêchera pas chaque grief de devenir une occasion d'éprouver la force relative des parties et de les faire rechercher une victoire plutôt qu'un règlement juste et équitable.

La bonne foi c'est le lubrifiant du mécanisme de griefs. Lorsqu'elle existe, les griefs sont rapidement réglés, que le contremaître ait peu ou beaucoup d'autorité, que le grief soit écrit ou non, qu'il y ait ou non des délais limite pour les réponses de la Compagnie et les appels de l'Union. La bonne foi à elle seule pourrait même dispenser de la procédure de griefs.

Donat QUIMPER.

\section{COLLECTIVE AGREEMENT ACT (Cont'd)}

sub-entrepreneur or sub-contractor and any intermediary for the payment of the wage fixed by the Decree (Art. 14).

N. B.-It is to be noted that the employer who habitually has only one employee in his service is not regarded as a professional employer within the meaning given to this term by the Act.

VIII.-Effects of the publication of the Decree:

The publication of the Decree in the Quebec Official Gazette bars any contestation with respect to the incapacity of the parties to the agreement, the invalidity thereof and the insufficiency of notices; and in all other respects it creates generally a presumption «juris et de jure » which establishes the legality of all proceedings relative to its adoption (Art. 15).

N. B.-In law there are two types of presumption: the presumption «juris tantum》 and the presumption 《juris et de jure». A presumption «juris tantum 》 is one which holds good in the absence of evidence to the contrary, but may be rebutted. On the other hand, a presumption «iuris et de jure 》 is an irrebuttable presumption which the law will not suffer to be rebutted by any counter evidence but establishes as conclusive.

\section{IX.-Duration of the Decree:}

The Decree becomes effective:

a) from the date of its publication in the Quebec Official Gazette

b) or from a later date therein fixed (Art. 7), and

c) has the same duration as the collective labour agreement which it renders obligatory (see Labour Relations Act, Art. 15).

By Order in Council, which must always be published in the Quebec Official Gazette, the Decree can:

a) be extended,

b) be repealed at any time, and

c) be amended at any time by the Lieutenant Governor in Council after consultation with the contracting parties or upon the express request of such parties.

The extension of the Decree takes effect from the date of its adoption

The repeal of the decree only takes effect from the date of its publication in the Quebec Official Gazette.

The amendment of the Decree takes effect as from the date of its publication in the Quebec Official Gazette or from a later date therein fixed. (Art. 8.)

Marcel FORGET 